\title{
An Analysis of Teacher's Strategies in Teaching Reading Comprehension
}

\author{
Yesicha Audina $^{1]}$, Nibenia Zega ${ }^{2]}$, Asima Simarmata ${ }^{3]}$ Kiki Velina Situmeang ${ }^{4]}$ \\ Sri Ninta Tarigan ${ }^{5]}$ \\ Universitas Prima Indonesia \\ E-mail: ${ }^{1]}$ yesichaaudina1994@gmail.com \\ ${ }^{2]}$ nibeniazega212@gmail.com \\ 3] asimasimarmata819@gmail.com \\ ${ }^{4]}$ situmeangk2@gmail.com \\ ${ }^{5]}$ srinintatarigan@gmail.com
}

\begin{abstract}
This study was raised due to problems in learning reading. The researchers saw that teachers and students experience constraints in the learning process. The problem is when students do not understand the content of the reading because students only learn to translate word by word and do not understand the contents of the reading. The purpose of research is to know the strategies used by English teachers and the reasons why did the English teacher choose those strategies to teach English reading comprehension and describe the application using the strategies chosen by English teachers in reading understanding learning. This research is used with research objects of English teachers. The location of this research was at SMK Dharma Bakti 1, Medan. The method of the research was qualitative research. The Instruments of this research were observations and interviews. The results of this study using the strategy of Directed Reading Activity (DRA). DRA is a strategy used to expand and strengthen students' reading skills. In short this strategy guides students to get information from a text read. So that in its implementation students can more easily understand the text of connecting the various student knowledge that students have. Before it was to build its own understanding and this assumption, this strategy was considered effective because it was able to build a teaching learning process. Making classes more conducive, students are also trained to build good cooperation, students capable of discussion and critical thinking as well as developing understanding after reading.
\end{abstract}

Keywords: Teacher Strategy, Teaching, Directed Reading Activity

\section{Analisis Strategi Guru Dalam Mengajar Pemahaman Membaca Di SMK Dharma Bakti 1 Medan}

\begin{abstract}
Abstrak
Penelitian ini diangkat karena melihat masalah dalam pembelajaran pemahaman membaca. Peneliti melihat bahwa guru dan siswa mengalami kendala dalam proses pembelajaran. Masalah yang ditemukan adalah ketika siswa tidak mengerti akan apa yang dibaca karena siswa hanya mengartikan kata demi kata dan tidak mengerti isi dari apa yang dibaca oleh siswa. Tujuan penelitian adalah untuk mengetahui strategi yang digunakan oleh guru bahasa inggris dan alasan
\end{abstract}


mengapa guru bahasa inggris memilih strategi pembelajaran tersebut serta mendeskripsikan penerapan menggunakan strategi yang dipilih oleh guru bahasa Inggris dalam pembelajaran pemahaman membaca. Penelitian ini digunakan dengan objek penelitian guru bahasa inggris. Lokasi penelitian ini di SMK Dharma Bakti 1, Medan. Metode yang digunakan dalam penelitian ini adalah metode penelitian kualitatif. Instrument penelitian ini adalah observasi dan wawancara. Adapun hasil penelitian ini, guru menggunakan strategi Directed Reading Activity (DRA). DRA adalah strategi yang digunakan untuk memperluas dan memperkuat kemampuan membaca siswa dengan memotivasi, melatih, dan menindak lanjuti pemahaman membaca siswa. Singkatnya, strategi ini membimbing siswa untuk mendapatkan informasi dari suatu teks yang dibaca. Sehingga dalam implementasinya siswa dapat lebih mudah memahami teks dan menghubungkan berbagai pengetahuan siswa yang telah dimiliki siswa sebelumnya untuk membangun pemahamannya sendiri atau asumsi. Strategi ini dianggap efektif karena mampu membangun proses belajar mengajar, membuat kelas lebih kondusif, siswa mampu berdiskusi dan berpikir kritis serta mengembangkan pemahaman setelah membaca. Dengan menggunakan strategy Directed Reading Activity (DRA) siswa juga dilatih untuk membangun kerjasama yang baik serta menyatukan pemikiran pemikiran yang di dapat dan dipahami dalam proses membaca.

Kata Kunci: Strategi guru, mengajar, Directed Reading Activity

\section{INTRODUCTION}

Language is the human ability to communicate with other humans using signs, for example words and gestures. Language is a tool to communicate and build relationships with other people. We used language to express our feeling, ideas and wishes. The language can be specialized, vocal or other, to express thoughts or feelings, especially words or gestures such as a code that has meaning still. People should learn how to communication correctly with used a language. A communication will be easy if the object can understand what is the sender and the receiver delivered. Language has an important role in the development of students ' social and emotional. Because the language can support students in learning all subjects, especially within the social. The language has been learned since we are in the womb, the potential of the baby was already starting to hear the voice of the mother and have learned the language of his mother. In language learning a lot of things are included in it. For example aspects are linguistic aspect which covers grammar, vocabulary, pronunciation, structure, and so on. Beside those aspects, the learners also need to master the skills of the language such as listening, writing, reading, and speaking. We should know that those skills cannot be learned discretely. Because of all the skills that are related to each other. And if we want to learn English we have to know and master those skills.

Reading is a process of a process performed someone by staring at reading and processing the information in the reading is in the brain, there is a reading in the heart without sound of da tone is also read by issuing a sound. Reading is a process to obtain information, in order to understand the significance or meaning of the text read. Most people argue that reading without meaning and comprehension is not reading. Reading is a crucially important language skill because people will get any knows ledge and experience and information from the text. Yang and Gao (2012) 
expressed that intensive reading is useful to develop reading comprehension.

The purpose of reading is to give information to others, a thing that can build and hone our knowledge in certain things. Or in other words, reading is very help students gather information and to expand their experiences about the world they live in. Reading is how we can understand and understand so that the message can be well received. It can be concluded that in reading the reader will actively find out the meaning of the text while also exploring the meaning of text while reading, the questions after they have their own understanding toward the text they read.

Reading is an activity undertaken of a person to analyze to get the message or meaning that is to be delivered by the author in the text of his reading. With the students are lazy to read, the students will be difficult to get new knowledge for themselves. In teaching a second or foreign language, reading gets special focus is different by reading on the lesson using the Indonesian language. Reading is a process of understanding. And this means that when we read the reader unconsciously trying to understand the meaning of the text to understand the purpose of the text, and the reader can make their own conclusions about the text after reading the text with the focus. How much and how easily the reader understand depending on the concentration of the reader and his ability in analyzing the text. If the students master the vocabulary better it will also be better for the students to understand the meaning and the purpose of the text, and to train the ability of the students to guess the information which derived from their past experience.

Reading skill is an achievement for people who are serious and focus in reading. Reading will open a window, many of the insights in the can and be one of the ways to obtain as much information as possible.
With this students have to understand and know what the purpose of that text is. With this students must be able to comprehend, identify, and interpret what they have read. Therefore, the students must have serious effort to study reading. To make it easy to understand we need a strategy. The strategies are used in combination to solve problem and to easier to get information from the text. The researchers believe that reading has a very complex process and important subject to teach for the learners. This gives teacher very important role to facilitate English reading lesson. They should be able to design lessons to make students comfortable in class, make the atmosphere not boring that they are interested and enthusiastic in reading activities. In this case the teaching reading technique of reading skill is necessary for the English teachers. They should have the appropriate techniques to teach English especially teaching reading more effective because it is the factors whether the teaching will be success or not.

The problem is when student do not understand the content of the reading because the student only translate word by word without understand the meaning what the content of reading. From this case researcher found so many teachers asked student to read the text and answer question without understand the text before, finally the students got a low score and the teacher banned their students that they are not able in reading comprehension. In the school so many student not able to comprehend the text, and so many student consider for granted reading comprehension.

Based on this factor the researcher interested and chose this topic "The analysis Of Teachers Strategies In teaching Reading Comprehension". The writer expected to analyze English teacher strategies the researcher want to know what English teacher strategies are use and how the 
English teacher implement the strategies in teaching reading comprehension to solve this problem.

An analysis teacher strategy in teaching reading comprehension is that the main of this research. Therefore, research questions of this research are:

1. What are the strategies of English teachers in reading comprehension?

2. Why did the English teachers choose those strategies to teach English reading comprehension?

The researchers aim to find out the teacher strategy in teaching reading comprehension. The specific objectives of this research are:

1. To find out the English teacher strategy in teaching reading comprehension

2. To describe the reason English teacher using the strategy to teach reading comprehension.

The researcher only focus on what kind of teaching strategy employed by English teacher in teaching reading comprehension and how to the implement of the strategy.

The finding of the present study are expected to enhance the theory about English teacher strategy in teaching reading comprehension and support evidence to exiting research finding, which is revealed the importance of having experimenting in teaching reading strategy in reading comprehension.

Practically, this study is expected to give contribution to the students, English teachers, and the next researchers.

1. For the student, the finding of the research can be used as a new reference to learning English especially in reading comprehension. They can learn English comprehension with the different way and they can understand what is their teacher strategy and what their teacher used to teach reading comprehension

2. For English teacher, to solve the teachers problem when teaching reading comprehension and to know how good the teacher strategy to teaching reading comprehension and teacher know how to implied that strategy

3. For the next researcher, this thesis will give some contribution and information for the next researcher about strategies in reading comprehension. The result of the research is expected to give some contributions for student, teachers and the next researcher.

\section{Analysis}

Analysis is an activity to search for a pattern in addition, the analysis is a way of thinking related to test systematically against something to determine the relationship between the part and its relationship to the whole Sugiyono (2014). In another meaning analysis is an activity that contains the activities of sorting out, differentiating something which is then classified and grouped according to certain criteria and then look for the meaning and their respective relationships. Analysis is the elaboration of a subject on the various parts and a review of the part itself, as well as the relationships between the parts to obtain an appropriate understanding and understanding of the overall meaning.

\section{Teaching reading strategies Teaching Reading}

Teaching is an activity to transfer the knowledge to the students. Moreover, teaching is an art; teachers must have art to make students enjoyed learning or to make the class exciting. Teaching is not only activity to transfer knowledge but also to help students learn and give students motivation. Teachers should be able to make students understand with the concept and the 
purpose of reading comprehension and teacher must help student to know what the text is about. In this case teacher is the mean point when learning English Learning Comprehension.

A good teacher needs to explain the comprehension strategies and teach to students when and how the strategies should be used.

\section{Teaching Strategies}

According to Dafid (2011), strategy is a shared means of purpose a length to reach. Strategies in learning can make a process of learning can be active. Teaching and learning activities are interrelated system. The system consists of components such as, teachers, students, and facilities. Every single component has its own role in teaching and learning. The teacher have been set the lesson plan, teacher has to teacher prepare the trick in order to create efficient and effective teaching and learning activities. The trick is called teaching strategy

\section{Reading Comprehension}

Mikulecky (2011:5) states that reading is a complex conscious and unconscious mental process in which the reader uses a variety of strategies to reconstruct the meaning that the author is assumed to have intended, based on data from the text and from the readers prior knowledge.

Comprehension is the ability to understand about something. The main point in reading is comprehension. Moreover, Cahyono (2011) states that reading is means of transferring information between the writer and the reader. Therefore reading comprehension understands a written text means extracting the required information from it as efficiently as possible. Reading with comprehension means understanding what has been read. It is an active, thinking process that depends not only on comprehension skills but also on the student's experience and prior knowledge. Comprehension involves understanding the vocabulary seeing the relationship among words and concepts, organizing ideas, recognizing the author's purpose, making judgment, and evaluating.

Reading comprehension understands a written text means extracting the required information from it as efficiently as possible. Reading with comprehension means understanding what has been read.

Reading comprehension means understanding, evaluating, and utilize of information and ideas gained through an interaction between reader and the author. Reading comprehension is such a kind of dialogue between an author and a reader in which the written language becomes the medium that cause the dialogue happen when the two persons communicate through the medium of print. Reading comprehension depends on many factors:

a. The reader's ability to attend the printed idea;

b. The reader's background knowledge to which new information must be added

c. The quality of writing it self

d. The reader's purpose or goal in reading material. In this research student understand about reading and teacher more to be active in teaching activity.

\section{Strategy in Reading Comprehension}

1. Directed Reading Activity (DRA)

Directed Reading Activity (DRA) is a strategy that provides student with instructional supports before, during, and after reading (Betts:2012) This strategy is intended for students to have a clear reading purpose by linking the various knowledge students have previously had to build understanding. Assuming, understanding can 
be improved by building a background of knowledge, compiling special purposes of reading, discussing, and developing understanding after reading. DRA serves several purposes:

- Teaches word identification skills.

- Elicits students' prior knowledge of the topic of the text.

- Teaches specific reading skills.

- Sets a purpose for reading.

- Encourages students to monitor their comprehension while they are reading.

\section{Think Aloud}

Jahandar et al. (2012) say that using the Think Aloud Method in teaching EFL reading comprehension will enable students to raise their awareness of becoming strategic readers. Also for teachers, using the Think Aloud Method will provide information about the needs of individual students and will enable them to provide appropriate instruction for students learning reading to improve their comprehension. There are five basic steps when using thinkaloud. First, select passage to read aloud that contain points of difficulty, ambiguities, contradictions, or unknown words. Second, while orally reading thinking-aloud, have students follow silently and listen to how trouble spots are through. Third, have students work with partners to practice think-aloud by taking reading short, carefully prepared passages and sharing thoughts. Fourth, have students practice independently, using a checklist to involve all students while verifying use of the procedures. Finally, to provide for transfer, integrate practice with other lessons, and provide occasional demonstration of how, why, and when to use think- aloud.

Five points that can be made during thinkaloud are showing how

1) To develop hypotheses by making predictions
2) To develop images by describing pictures forming in one's head from the information being read,

3) To link new information with prior knowledge by sharing Analogies

4) and to monitor comprehension by verbalizing a confusing point

5) To regulate comprehension by demonstrating strategies.

\section{PQRST}

In reading comprehension, one method that can be applied is the PQRST method. Sumarwati \& Purwadi (2010: 35) explains the steps in applying the method. PQRST is as follows:

1) Students are guided by the teacher conducting a review;

2) Students are guided by the teacher to formulate questions by changing the titles / subtitles and important parts found during the review into sentence questions;

3) Students are asked to read actively and carefully by paying attention to questions that have been formulated, pictures, summaries as a guide in regulating the focus of attention, marking the main ideas of each paragraph, capturing reading ideas, and stopping eye movement for a moment only at an important part in the reading;

4) Students are asked to state concisely the contents of the reading in their own words, both in their hearts and in a voice by answering questions that were formulated at the beginning of the activity or explaining the main topics and images that are there; and

5) Students respond to questions provided by the teacher, both verbally, written, and practice to measure the level of understanding. 


\section{SQ3R}

The method SQ3R is a learning model that guides students to understanding the subject matter systematically, increasing activity, and independence students and make it easier for students to learn, because this model is directly directed on the essence that is on the subject of the study (Susanti, \& Yulita, 2016). SQ3R is a systematic reading strategy to help you organize the reading process into manageable units. It is only one of many similar strategies that you can use to improve comprehension. It consist five steps, they are: Surveying, questioning, reading, reciting, and reviewing.

The SQ3R strategy involves:

1) Reading the headings in the chapter quickly to get its important part,

2) Turning the heading in to question,

3) Reading to find the answer to the question,

4) Recall the important point (the answer to the question) by retelling them or writing them in one's memory at the important point.

A summary of the SQ3R strategy procedure is presented a more detailed description of each step is presented in the following section:

\section{a. Surveying}

Before reading the text, the readers survey the text to get the general ideas of the text. This activity is done systematically in only a few minutes. The readers are required to find the important ideas quickly

\section{b. Questioning}

Questioning step is the second step of the SQ3R procedures. It is done before the actual reading. The students create some questions based on what they have surveyed. The main function of such questions is to facilitate students in adjusting their reading purposes.

c. Reading
The third step of the SQ3R procedures is reading. The students are required to read the text carefully to find the answer to the questions key have made. According to Somadayo (2011) reading is process that carried out as well as used by readers to obtain the messages to be delivered by the authors through the media said or material wrote.

\section{d. Reciting}

The fourth step of SQ3R procedure is reciting. This activity is done after the students read the text. Having read the text, the students answer the questions that have been formulated earlier without looking back at the text. The students have to answer not only by using the information they find in the text but also by using their own knowledge.

\section{e. Reviewing}

Reviewing is the last step of the SQ3R strategy. It is done by the students be reading the important part of the text. Huda (2014) states a strategy of the understanding that helps students to think about the text, they were read. Often be categorized as a strategy of learning SQ3R helps students to get something when the first time reading the text. For teachers SQ3R help them in guide student how to read and think like the reader effective.

\section{METHOD}

This research used qualitative method that research by doing observed to the object of the research and analysis them logically. Based on this method then the method used in the study is a descriptive method, base on the place this study is a field study. According to Setyosari (2010) the researchers who the goal is to explain or the description of an event, the state, the object is people, or everything associated with various that can be describe good with 
numbers and use the world,. The researcher found some things in this study, such as; what strategies were used to improve students' reading skill, then how students responded to the reading teaching used by their teacher.

In this research, the researcher has used the English teacher as a research object. The location of the research was at SMK Dharrna Bakti 1 in Jalan Letjen Jamin Ginting Km. 8 Padang Bulan, Medan. The researcher choose this school because there is no researcher who conduct the research previously with this topic

The research data used is obtained from the result of observations and interviews. Data from observations is required to know what strategies are used in the classroom and to know strategies in the English teaching learning process to tenth grade SMK Dharma Bakti 1 in Jalan Letjen Jamin Ginting Km. 8 Padang Bulan, Medan for the primary data, to complete the data and avoid misinterpretation while analyzing them, the author also conducted teacher interview. The data will be obtained in the form of field notes and presented descriptively in the form of paragraph. So the author directly know what the happen in that moment.

Research instrument are a means of collecting data. The research result are better, more accurate, complete and systematic. The author uses two instruments in collecting data. In this study, the author used observations and interviews.

To obtain data as stated above. The author had arranged the instruments properly. The research instruments had been designed by considering the characteristics of research objects. Therefore, the researchers used the instruments below:

\section{Observation}

Obervation is a technique of collecting data by making direct observations of an object in a given period with the goal of identifying and understanding events that occur in the study. Arikunto (2010) states observation is an observation directly against an object presents in that environment either in progress or still in stages covering various intentional activities to an object studies using the sensing.

In this case, researchers analyze all activities within the classroom during learning process. Researchers also observed teachers during the teaching and learning process. In making observations, researchers observed how teachers teach students about reading comprehension and what strategies teachers used in the classroom during the learning process from opening until closing. In this case researchers also observed activities conducted by English teachers related to teacher strategies in teaching reading in class.

\section{Interview}

Interview is one of way to obtain the data. Interviews are used to collect data from subjects' opinions, beliefs, and feelings about the situation in their own words. The interview can be divided into two things namely, structure and unstructured or semi structure interview. According to Moleong (2010) Interview is conversations with specific purpose. The conversation was conducted by two parties, namely the interviewer (who asked the question) and interviewed (who gave the answer to the question).

In this case, the researchers conducted interviews with English teachers using structured interviews. Interviews are conducted after completing the teaching and learning processes within the classroom. The purpose of doing this interview was to get oral responses from the participant. The function of interviews within this study was to cross-check the data and ensure that the 
data from the observations were completely valid.

Technique of collecting data, is a process or activity carried out by the researchers to obtain data and information, both in the observation of the learning process and interview the English teacher. In this research, the writer has carried out the technique of collecting data in the following way:

1) The first researchers preparing the material for making observations follows: Pen, Camera, and Paper.

2) Researchers into the class, joining and observe the learning process in the class.

3) After observed author of making observations against a strategy that carried out by the teacher while teaching.

4) After learning finished, the Researcher interviewed the teachers that use the methods or strategies, and asks about the teaching system and other data related to the application of the all methods or strategies. And also, the writer asked the teacher documentation.

Data analysis is a process of collecting the data is turning it into accurate data so that such data to be useful for other people who read it. In the definition of the other data analysis is activities performed to change the data the result of the research into information that can later be used in the conclusions.

The researchers used descriptive in the data analysis technique. In this research, the writer interviewed the teacher, observed to the teacher and the students in the teaching-learning process. Then the writer described the interview result, the observation result and the influence of the all methods or strategies used by the teacher in teaching reading through the students' reading responses.

\section{FINDINGS AND DISCUSSION}

This chapter presents information about analyzing teacher strategy in teaching reading comprehension. The writer observes on of the English teacher at SMK Dharma Bakti 1, Jl. Letjen Jamin Ginting Km.8 Padang Bulan, Medan. This data is obtained from observations and interview.

This chapter the researcher observe and interview, in this case the researcher just observe the class situation from the back row of the class and give an attention about what is student and teacher about what is student and teacher activity in the classroom. The researchers also make an interview; give some questions to teacher about the strategy in teaching reading comprehension. According to observation and interview, the researchers get information that the strategy used by teacher in teaching reading comprehension is Directed Reading Activity (DRA).

Directed Reading Activity (DRA) is a one of teaching reading strategies and DRA has a principle. The principles of Directed Reading Activity (DRA) focus to give an attention to student who learn English reading comprehension and change the learner mindset when learned English reading comprehension. to motivated the learners to have a skills and strategies and also motivated the lerners to have a self monitoring.

According this statements the researchers can explained the principle Directed Reading Activity (DRA) strategies. there are four the explanations about DRA strategies, first, DRA must be focus and give attention when teacher and the learners learned the english reading comprehension. the teacher and learners must be based on what is the reading context to get what is the meaning of reading to improved the reading skills and the strategies in learning reading comprehension to identyfy the word, sentences and pharagraph. second, when 
student identify the word, get information, references and the meaning information they can change the new way to get it. Third, to motivated the learners to have a strategy and skills tonexplore and develop their conceptual prior knowladge by the text andesthetically. fourt, to motivated the learners to self-monitoring when they reads the text they con know what is the strategiis needed.

When learning Teaching reading comprehension we must to know what is the characteristic of Directed Reading Activity (DRA), A several explanation about DRA. The caracteristic are.

1. The learners know ofentimes related with what they get from the text

2. Monitor the text meaning

3. To repair the faulty

4. Easy to different where is the important information

5. Syncornize what is they have read with what is they found in reading experience

6. Make inferences before and after reading

7. Almost always unconsciously, ask question on themselves, the authors mean in the text they read.

From this description the researcher can explained why this strategies is choose. This strategies can make the learner creative and effective readers when use background knowledge to emphasize word recognition and comprehension what is they reading and get from the text and after that connecting with what are the know before read the text. Easy to make a different where is the important information. Directed Reading Activity (DRA) can make learners understand with what are they read, and this is not individual work but students do this by collectively. This strategy also can do by all reader level, so all of teacher can use this reading strategy. Directed Reading Activity (DRA) also can build the student ability in critical thinking, especially to improve their vocabulary.

Hence, (Betts: 2012) has opinion about the step before doing Directed Reading Activity (DRA). There are some steps before doing this strategy:

1. Choose what the text you want to use

2. Select the vocabulary

3. Get the knowledge before

4. Teach student a specific skill

5. Give a student the foundation from the reading purpose

6. Give student read silently

7. As a question set the purpose of statement

8. Engage students in follow-up activities

Based on the finding in this study, the researcher has found a strategy that is used by teacher of SMK Dharma Bakti 1 Medan. The strategy used by teacher is used by teacher is Directed Reading Activity (DRA). The teacher chooses this strategy because it is considered easier for students to get information from the text. Besides that it does not take a long time to understand the text. Some questions are asked to ascertain whether or not students really understand the reading Directed Reading Activity (DRA) require students to activate both literal and critical thinking skills. If students do not understand the text well then the teacher then takes action to re-explain which part is difficult to understand. This strategy is considered effective because the teaching and learning process is always guided by teacher to focus more in the text.

Things that are not too complicated certainly make student more comfortable to learn. They look more relaxed carrying out learning but get the right meaning contained in the reading. The teacher is also not difficult to teach because Directed Reading Activity. 


\section{Disadvantages of Directed Reading} Activity (DRA)

1. A strategy Directed Reading Activity (DRA) often seized read a lot of time if management of the class is not efficient.

2. Strategy Directed Reading Activity (DRA) often required the provision of reading books and often beyond the capacity of the school and students.

3. Through understanding of reading immediately information can't be obtained quickly, different if gaining abstraction by presenting orally by the teacher.

This strategy that the teacher used Directed Reading Activity (DRA), Directed Reading Activity (DRA) this strategy to help student to get a comprehending when process teaching and learning reading comprehension. Directed Reading Activity (DRA) is a strategy to support a learning process from before, during and after reading. The teacher has to be an important part in this strategy. Teacher must be active to give a question, to give student a skill in vocabulary and monitor the student during the learning process. Come to student and ask student one by one about what is they read. After they read the text teacher focus to next activity and focus to what is the purpose of read. And focus to what is the text about and related it to what are student knowledge to what is student get from the text. From this explanation, it can be expected that the teacher must be active to do this strategy and must be active to give a question to the students.

\section{CONCLUSION}

The conclusion of this research is the English teacher choose the strategy Directed Reading Activity (DRA), this strategy are considered to be the most effective. The teacher made the student is quicker to understand the contents of and meaning text with the way Directed Reading Activity (DRA). During the process of reading the role of the teacher to be more active.so that student easy to understand the meaning of the text because text guided completely during the process of reading.it is expected to student were able to build a critical thinking as well as student also build opinion.

Directed Reading Activity (DRA) is a design to plan of learning and improve understanding read students, the increase interest in reading can be done a model a learning DRA. The teacher also need to provide opportunities for students to choose the reading, a model of learning packed is interesting and fun with a medium that supports. The student will be more active and excited in the following the productive. Directed Reading Activity (DRA) is the structural comprehensive strategy and can be used to teach the development of the guidance by teacher.

\section{SUGGESTION}

1) The teacher to be more improve the quality of in English so in the learning process teaching more efficient. A strategy of Directed Reading Activity (DRA) is a strategy effective used in the understanding of the reading.

2) Hopefully the students more often practice understanding read as a strategy thought and there is no reason not understanding the meaning of the text that there has been.

3) The researchers hope to hold the research into the more spacious so that the researchers know a strategy of what used the teacher to teach.

This is the reasons why this strategy is choose because this strategy can make the student enjoy their lesson, can make student improve the reading skills and make students understand with what are they read. 
Student also, can do this strategy with the kinds ways like can do with the individual, divide into some groups or with an entire groups. This strategy also help the teacher to make the student has a critical thinking with related what are they know with what are they read. And adding, this strategy can do by all reader levels. Event thought this strategy have some advantages teachers can make it easy with how to teacher teach his/her class. This is the process to make student understand and know how to improving and solve the problem when they learn about English reading comprehension.

\section{REFERENCES}

Arikunto, Suharsimi. 2010. Prosedur Penelitian Suatu Pendekatan Praktek, Jakarta: Rineka Cipta

Betts, (2012). DRA (Directed Reading Activity)". Retrieved On May 23 2012, from, http://www.nea.org/tools/DRAdirected-reading-activity.html .

Cahyono, B.Y. 2011. The Teaching

Language Skill and English Language Components Malang. State university of Malang Press.

Dafid, Fred, R. 2011. Strategi Manajement Strategi Konsep, Edisi 12, Jakarta : Salemba Empat,

Huda,M. (2014). Model-model pengajaran dan pembelajaran. Yogyakarta: pustaka pelajar.

Jahandar, S., Khodabandehlou, M., Seyedi, G., \& Abadi, R. M. D. (2012). The Think Aloud method in EFL reading comprehension. International Journal of Scientific and Engineering, 3(9), 1-9.

Mikulecky, B. S. 2011. A short course in teaching reading: Practical technique for building reading power. United States: Pearson Longman.

Moleong, L. J. 2010. Metodologi Penelitian Kualitatif, Bandung: Remaja Rosda Karya.

Setyosari, Punaji. 2010. Metode Penelitian Pendidikan dan Pengembangan. Ed. 1; Ed.2; Cet. 1 Jakarta; Kencana, 2010. Print.

Somadayo, Samsu. 2011. Strategi Dan Teknik Pembelajaran Membaca. Yogyakarta: Graha Ilmu.

Sugiyono, 2014. Metode Penelitian Pendidikan Kuantitaf, Kualitatif, dan $R \& D$. Bandung: Alfabeta.

Sumarwati \& Purwadi. (2010). Pembuatan Pertanyaan Awal pada Kegiatan Prabaca untuk Meningkatkan Kemampuan Membaca Intensif". Diksi, 17 (1), 2- 6.

Susanti, S., \& Yulita, D. P. S. 2016.

Pengaruh Penerapan Metode Pembelajaran SQ3R (Survey, Question, Read, Recite, And Review) Terhadap Hasil Belajar Mahasiswa Prgram Studi Pendidikan Sejarah. IKIP PGRI Pontianak. Edukasi: Jurnal Pendidikan, 13(1), 97-104.

Yang, Dai, W., \& Gao, L. (2012). Intensive Reading And Necessity To Integrate Learning Strategies. English Language and Literature. 